American Journal of Applied Sciences 6 (9): 1718-1724, 2009

ISSN 1546-9239

(C) 2009 Science Publications

\title{
Income Statements Transparency and Firms' Characteristics of Companies Listed on the Bursa Malaysia
}

\author{
${ }^{1}$ Sazilah Mohd Saad, ${ }^{2}$ Syed Noh Syed Ahmad, ${ }^{3}$ Kamaruzaman Jusoff, \\ ${ }^{1}$ Mazlifa Md Daud and ${ }^{1}$ Maisarah Abd Rahim \\ ${ }^{1}$ Faculty of Accountancy, University Technology MARA, P.O Box 187, \\ 08400 Merbok, Kedah, Malaysia \\ ${ }^{2}$ Faculty of Accountancy, University Technology MARA, Malaysia, \\ Menara SAAS, 40450 Shah Alam, Selangor, Malaysia \\ ${ }^{3}$ Faculty of Forestry, University Putra Malaysia, 43000 Serdang, Selangor, Malaysia
}

\begin{abstract}
Problem statement: This research was intended to contribute to the one of Corporate Governance mechanism on transparency and disclosure on the financial statements. Approach: As in the recent development of findings from Financial Statements Review Committee (FSRC) that company did not disclose of Material expenses and not classified accordingly. Results: This study provides an evidence for the transparency level on income statements with regards of firms' characteristics of 150 main and second boards companies listed on the Bursa Malaysia. The characteristics were grouped into three groups of variables: structural (firm size, leverage and number of shareholder), market related (listing type and industry type) and performance (profit margin, return on equity and liquidity). The study was started with the development of a Transparency Index based on the percentage of the details of expenses disclosed in annual reports (notes to the accounts) over the total expenses of the company. The findings suggested that this index on the average for the companies in the sample is about $64 \%$ with three companies scoring transparency index of $100 \%$. Both univariate and multivariate statistical analysis were performed on the data. The stepwise regression method indicated that only one variable was significant at $5 \%$ which was the Number of Shareholders (LnNOSH). The other factors were not significant. Hence, this study will contributes to the enhancement of knowledge regarding income statements transparency and disclosure practices under new reporting regime in Malaysia. Conclusion/Recommendations: This study also served as a basis for further research in this area. This study also suggested that further research should be done on longitudinal study basis for several years of data with more appropriate or suitable variables to the model.
\end{abstract}

Key words: Income statement transparency index, disclosure and transparency, firms' characteristics, stepwise regression method

\section{INTRODUCTION}

Financial statements should always provide reliable information to assist users in decision making. The statement should disclose relevant, reliable, comparable and understandable information. To be understood clearly, the presentation should not be misleading. Readers should be able to understand the information presented without undue effort according to International Accounting Standards (IAS) 1. To achieve this, the annual reports should contain full disclosure and higher level of transparency. As Thompson and Yeung $^{[23]}$ stressed that for a company to be transparent, disclosure means providing a full and frank account of a company's activities. In addition, as far as corporate transparency is concerned, it should be defined as the widespread availability of relevant, reliable information about the periodic performance, financial position, investments opportunities, governance, value and risk of publicly traded firm ${ }^{[3]}$.

Comprehensive disclosure of financial statement has been a world wide issue for a long decade. Malaysian market is currently promoting good corporate governance practices as a result of debacle of many big conglomerates in US as well as in Malaysia. As users of financial statement specifically income statement demanding for better disclosure of quality information and found that there are big amount of

Corresponding Author: Kamaruzaman Jusoff, Faculty of Forestry, University Putra Malaysia, 43000 Serdang, Selangor, Malaysia 
expenses portion goes to other operating expenses. The income statement is important because it reports on the operating performance of the company. The greater the transparency of income statement the more useful it will be for current and potential investor to make investment decision. In other words, the more the companies disclose, concerning the figures founding the financial statement, the greater the level of transparency. The current reform of the accounting and financial reporting in Malaysia which aims to promote transparency and to deliver high quality annual report is enhance through comprehensive disclosure. This change has contributed to the accounting standards setting and laws regarding financial reporting produced by local organizations.

The Section 167 and Ninth Schedule of the Companies Act 1965 govern the disclosure in the financial statements of companies in Malaysia. Under Section 167, states that each company must keep a proper set of books and accounts and the financial statements must contain at a minimum Profit and Loss Account, a Balance Sheet, a Cash Flow Statement and accompanying notes to the account. Schedule 9, details the item that the companies must include in the financial statements. Until the introduction of Financial Reporting Act 1997, the items in Schedule 9 represent the minimum statutory disclosure requirement for companies. It must be noted that the accounting standards issued by the Malaysian Institute of Accountants (MIA) and other professional bodies remains 'voluntary' disclosure requirement. In the case of listed companies, the regulatory agency that responsible is the Securities Commission (SC), the registrar of companies and the Central Bank of Malaysia. Their functions are to administering in public listed companies, administering companies incorporated in Malaysia and administering financial institutions respectively. This is to ensure enterprise financial reporting meeting the minimum requirements, if necessary go beyond that to achieve a fair presentation. The companies listed on the Bursa Malaysia must also meet the accounting and reporting guidelines as per issued by $\mathrm{SC}^{[22]}$. Each company that going to public market should administer good corporate governance by discloses full information necessary to make informed users investment decisions.

The Malaysian Code of Corporate Governance (MCCG 2002) had been introduced to promote greater transparency and adopt professional business ethics as well as convey this via their annual reports. The National Annual Corporate Report Awards (NACRA) held by the collaboration of Bursa Malaysia, MIA and the MICPA to help Malaysian companies aim for the greatest standards in annual reporting. Study of disclosures begins with research done by $\mathrm{Cerf}^{[5]}$. He constructed disclosure index by specifying and weighting some related items which might appear in annual reports. The index scores were positively correlated with firm characteristics namely asset size, number of shareholders and profitability ${ }^{[21]}$. Buzby ${ }^{[4]}$ was consistent with other researcher but add listing status as one of the variable to explain disclosure level.

Disclosures indexes tend to based upon lists of selected items if accounting information which may be disclosed in corporate annual reports and seek to measure the extent of disclosure by using numerical weights on items of accounting information. Extensive accounting literature relating to the use of disclosure indexes by way of measure the quality of information and it is vary among different studies. Inchausti ${ }^{[13]}$ reported that in some studies, only voluntary information were considered ${ }^{[7,9,19]}$ whilst in other studies rating for both compulsory and voluntary items was being included in an index ${ }^{[5,6,8]}$. Studies also differ in the aspects of items included in index from 17, Barret $^{[1]}, 39$ Buzby $^{[4]}$ and 224, Cooke ${ }^{[8]}$. In some studies, they compared the transparency or disclosure of accounting information in cross-countries ${ }^{[2,3]}$.

Transparency that also defined as level of disclosure in many previous research are measured by using CIFAR index introduced by CIFAR's International Accounting and Auditing Trends $(\mathrm{IAAT})^{[3]}$. The index represents the average number of 90 accounting and non-accounting items disclosed by a sample of large companies in their annual reports.

Most of the study employed a scoring sheet to grade the information disclosed in annual reports. As for the grading criteria concern, Thompson and Yeung $^{[23]}$ the CTI Index used a scorecard developed by Business Times (Singapore's financial daily) to see the level of transparency of 290 Singapore listed companies. Equal weighting to content and context were then analyzed. Multiple regression model was used to measure the association between selected company characteristics (size and profitability) and the transparency index.

Pauline and Mathew ${ }^{[18]}$ suggested that for study done for Malaysian companies, development of disclosure index has to consider the influenced by the approved accounting standards, national laws and other requirements. SC, Bursa Malaysia, Companies Act, 1965 and Malaysian Accounting Standard Board (MASB) were namely the regulatory bodies to encourage companies to provide more information that required and to enhance understandability of the items disclose in notes to the accounts. In Malaysia, 
Haniffa and Cooke ${ }^{[11]}$, Hossain et al. ${ }^{[12]}$ and Thompson and Yeung ${ }^{[23]}$ suggested that the comprehensiveness of disclosed information may closely associate with the conservativeness of accounting methods and full financial disclosure. Since many studies criticized on grading as weighted to the items disclosed ${ }^{[10]}$ Cooke $^{[8]}$ and this study follow alternatively. This objective is based on assuming that there will be a biased towards all items disclosed. Unweighted scoring approach was preferred in study done by ${ }^{[17,18,24]}$.

The various features used in the literature, such as number of firms included in the sample, type of firm, listing status, firm's size, used as independent variables to explain correlation with dependent variables. As for the dependent variables concerned, the numbers of disclosure item are normally used. These have contributed to mixed results. This study has constructed new dimension of transparency index. Therefore, the primary objective of the study is to see whether there is a relationship between level of transparency and firms' characteristics. In order to achieve purpose of this study a transparency index is developed. The items used in the development of transparency index were obtained from the financial statements of the companies. The significant of this transparency index is to be as an indication of the level of transparency in the income statements of the companies. This index is also used as a dependent variable in determining firms' characteristics that influence this index. Hence this study will help to identify areas which improve greater transparency of income statements of listed companies.

\section{MATERIALS AND METHODS}

Model development: This study constructs a transparency index by considering the all-inclusive concept of income. Similarly, this study uses an index to measure transparency of the income statements $^{[11,16,18,23,24]}$. According to the accounting requirements and regulations in Malaysia, the types of expenses to disclose are detailed in the Companies Act 1965 and relevant requirement of the accounting standards issued by MASB. Nevertheless, the quality of the income statement could be judged specifically of items reported in the income statements should be disclosed comprehensively on the notes to the accounts.

Construction of the transparency index was properly drawn up onto two stages. The first stage was the identification of total expenses as the total amount of selling and administration expenses, distribution expenses, other operating expenses and finance cost. Selection of these items were done after considering standardized items that were reported in the income statement regardless of whether firms are manufacturing or non-manufacturing. The definition of total expenses is shown below:
Total Expenses $(\mathrm{TE})=$ Selling and administration expenses + distribution expenses + other operating expenses + finance cost

A major difficulty in determining the total expenses are cost of ambiguous nature of certain expense item disclosure. For example, depreciation expense is not clearly identified as to whether it is in the cost of goods sold, selling and administration expenses and many others. In addition, the cost of sales may also lead to bias for non-manufacturing and trading companies, that is the service industries. Therefore, the item cost of sales or cost of goods sold is excluded from the total expenses (the denominator of the index) figure. Admittedly, this is a major limitation of the income statements transparency index but is unavoidable given the existing income statement disclosures of the companies. In addition, excluding a cost of sales or cost of goods sold avoids the problems of double counting, as companies are required to disclose depreciation expenses. This method of determining total expenses is applied consistently through all the sample firms. As for the numerator of the index, the total expense disclosed (the numerator) represents the detailed expenses disclosed in the notes to the accounts. In the notes to the account, the most relevant note will be the notes regarding the calculation of profit or loss from operations. The detailed expense item will then be used in calculating the index. In addition to the note regarding profit or loss from operations, other expenses are disclosed elsewhere in the financial statements, for example staff costs, in order to avoid double counting specifically regarding directors remuneration. Details of the staff costs have to be examined and necessary adjustment will then be made.

One difference relating to the determination of detailed expenses item disclosed is with regard to the adjustment for stock and debtors. These items are carefully examined to avoid double counting. The above procedure is used to construct the income statement transparency index for all companies in the sample. Thus, this is totally different with other measurements of transparency index that are used in the study done by Thompson and Yeung ${ }^{[23]}$-Corporate Transparency Index (CTI) that measured transparency by looking at the efficiency of process of information dissemination to public. In mathematical form, the income statement transparency index will be as follows: 
Income statement $\begin{aligned} \text { transparency index }= & \text { Total of } \text { Detailed }^{* 2} \text { Expense } \\ \text { Disclosed } & \text { Ex } / \text { Total Expense }\end{aligned}$

$* 1=$ Total of detailed expense disclosed is equal to detail expenses disclosed on the notes to the accounts as required by Schedule 9 of the Companies Act 1965 and MASB 1

$* 2=$ Total expenses is equal to the sum of the aggregated expenses in the income statementselling and administration expenses, distribution expenses, other operating expenses and finance cost

The income statement transparency index is expressed as percentage. The higher the transparency index, the more transparent the income statement of the companies.

Independent variables used in this study are categorized into three groups: structural (firm size, leverage and number of shareholder) and market related (listing type and industry type) and performance (profit margin, return on equity and liquidity). These variables are used in the regression model to determine whether these variables are significant in determining the level of transparency index in income statement. The hypothesis then developed to test the association between them.

'The full specification of the regression model is developed to fit the data in order to assess the effect of each variable on the transparency level:

$$
\begin{aligned}
Y_{T}= & \beta_{0}+\beta_{1} X_{1}+\beta_{2} X_{2}+\beta_{3} X_{3}+\beta_{4} X_{4}+\beta_{5} X_{5}+\beta_{6} X_{6}+\beta_{7} X_{7} \\
& +\beta_{8} X_{8}+e
\end{aligned}
$$

Where:

$\mathrm{Y}_{\mathrm{T}}=$ Transparency

$\beta_{0}=$ Intercept

$\beta_{1-8}=$ Coefficient of the independent variables

$\mathrm{X}_{1}=$ Firm size (lnasset)

$\mathrm{X}_{2}=$ Leverage (lev)

$\mathrm{X}_{3}=$ Number of shareholders (LnNOSH)

$\mathrm{X}_{4}=$ Industry type (Indtype)

$\mathrm{X}_{5}=$ Listing status (LS)

$\mathrm{X}_{6}=$ Profit margin $(\mathrm{PM})$

$\mathrm{X}_{7}=$ Return on equity (ROE)

$\mathrm{X}_{8}=$ Liquidity (Lqdty)

e $=$ Residual

A review of prior studies in this area highlighted the difficulty in identifying the association between the dependent and the explanatory variables. Several assumptions in regression analysis were first tested to ensure that, there was no significant multicollinearity problem between independent variables; the variance of the distribution of the dependent variable is similar for all values of the independent variables (homoscedasticity); a linear relationship exists between the dependent and independent variable (linearity); the distribution values of the dependent variable for each value of the independent variable is normal (normality) and that no errors related to measurement and specification exist, Haniffa and Cooke ${ }^{[11]}$.

Statistical analysis: The study attempts to reports the results of relationship between the income statements transparency index and firms' characteristics of 150 samples Main and Second Boards companies of the Bursa Malaysia. The 150 samples are taken randomly from the population of all 874 companies as at 31 December 2003. Each company has equal chance to be one of the samples. It represents $17 \%$ of the whole population. This is determined the number of sample used in studies in similar area, for example 63 firms by Pauline and Mathews ${ }^{[18]}$ and 49 firms by Inchausti ${ }^{[13]}$. This is consistent with the central limit theorem states that the more samples selected in the study to represent population, the more it can explain the population.

The measurement of independent variables is calculated as follow:

- $\quad$ Firm size (Lnasset) is measured as the total assets that refer to the sum of current and non-current assets at the end of firm's reporting year (2002)

- Leverage (Lev) is measured as the ratio of total non-current liabilities to owners' equity

- Number of shareholders (LnNosh) refers to the number of shareholders of the company that stated in analysis of shareholding part in the notes to the accounts

- Industry type (Indtype) is classified into manufacturing sector and non-manufacturing sector. It is a dummy variable and stated that manufacturing $=1$ and non-manufacturing $=0$

- $\quad$ Listing status (LS) is classified into main board and second board of firm listing on the Bursa Malaysia. It is a dummy variable and stated that main board = 1 and second board $=0$

- Profit margin (PM) is measured as the net profit after tax divided by net sales or revenue

- Return On Equity (ROE) is measured as the net profit after tax divided by total equity

- Liquidity (Lqdty) is measure as the ratio of current assets to current liabilities 
All these variables are tested based on the hypothesis whether it is a significant factor to the level of income statement transparency.

Pauline and Mathews ${ }^{[18]}$ suggested that log transformed data should be applied for skewed data set, namely for total assets. Natural log was also applied in this study to the number of shareholders variable, The other reason why the variable are logged is to eliminate outliers that exist within the huge data range from the larger to smaller firm and number of shareholder size. By doing so, it blends the data set to the extent, which can be guaranteed that the details of each data were taken into the statistical measure. The multivariate test performed was SPSS's stepwise multiple regression. It is used to test hypotheses developed in this study to see whether the independent variables have significant relationships in determining the level of transparency.

The stepwise regression is an iterative procedure that adds and deletes one independent variable at a time. The decision to add or delete a variable is made on the basis whether that variable improves the model. The procedure begins by computing the simple regression model for each independent variable by looking at the standard value of F-to-enter (usually 4.0) for each variable. The computer proceeds to produce regression model although one variable exceeds the F-toenter value and continue adding second variable as to determine which is best and whether the F statistic of the second variable is greater than F-to-enter and it continues to all remaining variables. Multicollinearity problem is reduced between highly correlated variables by included only one of them in the equation. Once the first variable is included, the added explanatory power of the second variable will be minimal and its F-statistic will not be large enough to enter the model. These steps are repeated until no more variables are added or removed ${ }^{[15,20]}$.

\section{RESULTS}

Table 1 below shows the descriptive analysis concerning income statements. This result fulfills the first objective of the study to determine the level of income statement transparency of firms listed on the Bursa Malaysia. The highest transparency index is 1.000 which means that the company fully disclosed all expenses reported in the income statement in the notes to the account. Three companies in the sample have perfect scores, namely LPI Capital Bhd, Maybank Bhd and John Hancock Life Insurance (Malaysia) Bhd. The lowest transparency index is 0.089 which means that detailed expenses disclosed in the notes to the account are only $9 \%$ of total expenses. The mean income statement transparency index score is 0.643 with standard deviation 0.239 .
Table 2 shows descriptive statistics for dependent and independent variables in the study. The bivariate correlation results indicate that the number of shareholder is the only variable that is significantly correlated with the transparency index; as shown by the Pearson correlation coefficient of 0.162 ( $\mathrm{sig}$. $=0.05$ ). The output also shows that Leverage (Lev) is another variable that is significant at $10 \%$. The correlation matrix shows that it is one highly correlated variable. However, there are no significant correlations between transparency index and firm size, leverage, return on equity, profit margin and liquidity.

Where TI = Transparency Index.

The matrix showed in Table 3 shows that number of shareholders (LnNOSH) variable has the strongest correlation with dependent variable (transparency index). The positive sign indicates the same relationship between them. The correlation matrix is also used to check the multicollinearity and it is found that the highest correlation between independent variables is 0.975 . The variables are leverage and profit margin ratio. Judge et al. ${ }^{[14]}$ suggested that high correlations between independent variables are considered "harmful" until they exceed 0.80 . Multicollinearity can distort the standard error of estimate and therefore lead to incorrect conclusions as to which independent variables are statistically significant. This problem, however, will be taken care of by a stepwise multivariate regression analysis. Regression analysis result fulfills second objective of this study which is to see the relationship between level of income statement transparency and firms' characteristics.

Table 1: Descriptive statistics for transparency index

\begin{tabular}{lllllll}
\hline & $\mathrm{n}$ & Min & Max & Mean & Std. dev. Variance \\
\hline Transparency index & 150 & 0.089 & 1.000 & 0.643 & 0.239 & 0.0575
\end{tabular}

Table 2: Descriptive statistic and univariate analysis for the independent variables

\begin{tabular}{|c|c|c|c|c|c|}
\hline & $\mathrm{N}$ & Mean & Std. dev. & $\begin{array}{l}\text { Pearson } \\
\text { corr. (r) }\end{array}$ & $\begin{array}{l}\text { Sig. } \\
\text { (2-tailed) }\end{array}$ \\
\hline Firm size (lnasset) & 150 & 7.491 & 1.2840 & -0.002 & 0.981 \\
\hline $\begin{array}{l}\text { Number of shareholder } \\
\text { (LnNOSH) }\end{array}$ & 150 & 3.712 & 0.4660 & 0.1620 & $0.048^{* 1}$ \\
\hline Listing status (LS) & 150 & NA & NA & NA & NA \\
\hline Industry type (Indtype) & 150 & NA & NA & NA & NA \\
\hline Leverage (Lev) & 150 & 1.206 & 5.8760 & 0.156 & $0.057^{* 2}$ \\
\hline Return on equity (ROE) & 150 & 0.054 & 0.7250 & 0.072 & 0.381 \\
\hline Profit Margin (PM) & 150 & -3.288 & 38.449 & -0.115 & 0.161 \\
\hline Liquidity (Lqdty) & 150 & 2.566 & 4.0390 & -0.001 & 0.995 \\
\hline
\end{tabular}

${ }^{{ }^{2}}$ : Significant at $5 \% ;{ }^{* 2}$ : Significant at $10 \%$

Table 3: Correlation coefficients between variables

\begin{tabular}{lrrrrrrr}
\hline \multicolumn{1}{c}{$\mathrm{ti}$} & \multicolumn{1}{c}{ lev } & ROE & PM & Lqdty & Lnasset & LnNOSH \\
\hline TI & 1.000 & & & & & & \\
Lev & 0.156 & 1.000 & & & & & \\
ROE & 0.072 & 0.015 & 1.000 & & & & \\
PM & -0.115 & -0.975 & -0.120 & 1.000 & & & \\
Lqdty & -0.001 & -0.100 & 0.145 & 0.060 & 1.000 & & \\
Lnasset & -0.002 & -0.029 & 0.005 & 0.008 & 0.075 & 1.000 & \\
LnNOSH & $0.162 *$ & 0.140 & 0.063 & -0.153 & -0.114 & -0.056 & 1 \\
*: Significant variable. Correlation at the 0.05 level (2-tailed)
\end{tabular}


Am. J. Applied Sci., 6 (9): 1718-1724, 2009

Table 4: Model summary

\begin{tabular}{|c|c|c|c|}
\hline Variables & $\mathrm{T}$ & Significant (5\%) & Coefficients \\
\hline Constant & 2.139 & 0.034 & \\
\hline LnNOSH & 1.998 & $0.048 *$ & 0.159 \\
\hline Firm size (Lnasset) & 0.088 & 0.930 & 0.021 \\
\hline Leverage (Lev.) & 1.667 & 0.098 & 0.962 \\
\hline Listing status (LS) & -0.637 & 0.525 & -0.012 \\
\hline Industry type (Indtype) & 0.554 & 0.581 & 0.022 \\
\hline Return on Equity (ROE) & 0.763 & 0.447 & 0.044 \\
\hline Profit Margin (PM) & -1.127 & 0.261 & 0.846 \\
\hline Liquidity (Lqdty) & 0.222 & 0.825 & 0.057 \\
\hline
\end{tabular}

r-square $=0.026 *$ : Significant variable at $5 \%=\mathrm{LnNOSH}$

The coefficients of the explanatory variables are estimated by using a model because the potential multicollinearity problem between variable will be minimized by using multivariate analysis. The SPSS stepwise multiple regression models includes all the explanatory variables, including both profit margin and leverage which are the variables with high correlations (multicollinearity).

SPSS stepwise multiple regression model will take into account all the four assumptions; multicollinearity, linearity, homoscedaticity and normality.

The procedure begins with all one-independentvariable models which means that in every step, each of the variables will be added or deleted. At the same time, with the addition of one variable to the model, the new Fstatistic value is calculated and compared to the F-to remove $(\mathrm{F}$-standard $=4.00)$. This procedure will be continued until no other variables are added to the model.

The regression equation below shows the best model produced with standard error of 0.2373 and coefficient of determination of $2.6 \%$ :

Income statement Transparency Index $(\mathrm{TI})=$ 0.334+0.08334LnNOSH

Table 4 summarizes the results from stepwise multiple regression which provide the significant value for each variable in determining the level of income statement transparency. The results indicate that there is only one variable significant, which is the number of shareholder. The other independent variables, however, are not significant. The result is consistent with the previous study by Buzby ${ }^{[4]}$. On the contrary, the results are different with the other researches ${ }^{[11,13,18,24]}$.

\section{DISCUSSION}

A possible explanation is due to the introduction of disclosure guidelines introduced by the MASB and Bursa Malaysia's listing requirement. Firms will have to obey the disclosure requirement regardless of their characteristics. In addition, firms with a higher number of shareholders normally have implement good corporate governance between the companies. A higher level of disclosure and transparency were then become a company's practices. This is to ensure the users of accounting information get the true view of financial statements and that contribute to the decision made by the investors to invest in their company. This is supported by the fact that the mean of transparency index of companies in the sample of this study is $68 \%$. Therefore, there is greater uniformity in term of the disclosure relating to the income statements. The low rsquared indicates that there are possibilities that certain variables are not captured by the model. It is probably due to the fact that measurement issues and level of enforcement. Examples of these variables are the share price, level enforcement and others.

\section{CONCLUSION}

This study aims to investigate the relationship between the transparency level of income statement (measured by transparency index) and firms' characteristics from the Main and Second Board companies of the Bursa Malaysia. The characteristics are separated into three groups of variables: Structural (firm size, leverage and number of shareholder) and market related (listing type and industry type) and performance (profit margin, return on equity and liquidity). The result shows, on average most of the companies account for about $68 \%$ of transparency level with three companies scoring a perfect $100 \%$ transparency index. Both univariate and multivariate statistical analysis are performed on the data.

The model also indicates that the number of shareholder (structural) is the only significant factor of the transparency level. The remaining characteristics are not significantly 'contributed' to the level of transparency. Hence, the regulators should enforce more on the voluntary disclosure among companies listed on the Bursa Malaysia as to ensure a higher quality of income statements. In addition, enforcement of the disclosure requirement for the companies can also be vital in determining the level of transparency. For example, a new regulation such as full and detailed expenses must be disclosed. As an emerging stock market, Bursa Malaysia should give specific guidelines to the companies so as to ensure the income statement as transparent as possible and at par with the companies listed in the more established market. In the era of globalization, the foreign investors, particularly the institutional investors have the confidence to invest in the Bursa Malaysia and it will be as strategy to improve Malaysian economy. 


\section{REFERENCES}

1. Barret, M.E., 1976. Financial reporting practices: Disclosure needs of comprehensiveness in an international setting. J. Account. Res., 14: 10-26. http://www.jstor.org/pss/2490455

2. Belkaoui, A. and A. Kahl, 1981. Bank annual report disclosure adequacy internationally. Account. Bus. Res., 11: 189-196.

3. Bushman, R.M. and A.J. Smith, 2003. Transparency, financial accounting information and corporate governance. Econ. Policy Rev., 9: 65-87. http://ideas.repec.org/a/fip/fednep/y2003iaprp6587nv.9no.1.html

4. Buzby, S.L., 1974. Selected items of information and their disclosure in annual reports. Account. Rev., 49: 423-435. http://www.jstor.org/pss/244603

5. Cerf, A.R., 1961. Corporate Reporting and Investment Decisions. University of California Press, $\quad$ Berkeley, $\quad 177$. http://openlibrary.org/b/OL5870846M/Corporatereporting-and-investment-decisions

6. Choi, F.D.S., 1973. Financial disclosure and entry to the European capital market. J. Account. Res., 11: 159-175. http://www.jstor.org/stable/2490187

7. Chow, C.W. and A. Wong-Boren, 1987. Voluntary financial disclosure by Mexican Corporations. Account. Rev., 62: 533-541.

8. Cooke, T.E., 1989. Disclosure in the corporate annual reports of Swedish companies. Account. Bus. Res., 3: 113-24.

9. Firth, M., 1979. The impact of size, stock market listing and auditors on voluntary disclosure in corporate annual reports. Account. Bus. Res., 9: 273-280.

10. Gray, S.J., G.J. Meek and C.B. Roberts, 1995. International capital market pressures and voluntaries disclosure by US and UK multinationals. J. Int. Finance. Manage. Account., 6: 43-63. DOI: $10.1111 / \mathrm{j} .1467-$ 646X.1995.tb00049.x

11. Haniffa, R.M. and T.E. Cooke, 2002. Culture, corporate governance and disclosure in Malaysian corporations. ABACUS., 38: 317-349. DOI: 10.1111/1467-6281.00112

12. Hossain, M., Tan L.M. and Adams M., 1994. Voluntary disclosure in an emerging capital market: Some empirical evidence from companies listed on the Kuala Lumpur stock exchange. Int. J. Account., 29: 334-351.

13. Inchausti, B.G., 1997. The influence of company characteristics and accounting regulation on information: An empirical analysis. Eur. Account. Rev., 6: 45-68. http://ideas.repec.org/a/taf/euract/v6y1997i1p45-68.html
14. Judge, G.G., R.C. Hill, W. E. Griffiths, H. Lutkepohl and T.C. Lee, 1985. Introduction to the Theory and Practice of Econometrics. Wiley, New York.

15. Keller, G. and B. Warrack, 2000. Statistics for Management and Economics. 5th Edn., Duxbury. Thompson Learning.

16. Lang, M. and R. Lundholm, 1993. Cross sectional determinants of analysts ratings of corporate disclosure. J. Account. Res., 31: 246-721. http://www.jstor.org/pss/2491273

17. Naser, K., 1998. Comprehensiveness of disclosure of non-financial companies: Listed on the Amman financial market. Int. J. Commerce Manage., 8: 88-119. DOI: $10.1108 / \mathrm{eb} 047365$

18. Pauline P.L.H. and M.R Mathews, 2002. Comprehensiveness of disclosure of non-financial companies: Some empirical evidence from annual reports of companies listed on the Kuala Lumpur stock exchange. Master Dissertation, Working Paper No. 26/02, Charles Sturt University-2002. http://catalogue.nla.gov.au/Record/621515

19. Raffounier, B., 1995. The determinants of voluntary financial disclosure by swiss listed companies. Eur. Account. Rev., 4: 261-280.

20. Sheridan, J.C. and G.S. Lyndall, 2003. SPSS Analysis without Anguish: Version 11.0 for windows Australian. John Wiley and Sons.

21. Singhvi, S.S. and H.B. Desai, 1971. An empirical analysis of the quality of corporate financial disclosure. Account. Rev., 46: 129-138. http://www.jstor.org/pss/243894

22. Tan, L.T., 2000. Financial Accounting and Reporting in Malaysia. 2nd Edn., PAAC., Malaysia, ISBN: 9839274147.

23. Thompson, P. and C.H. Yeung, 2002. The determinants of transparency for Singapore listed companies? Proceeding of the 10th Annual Conference of Pacific Basin Finance, Economics and Accounting, Aug. 7-8.

24. Wallace, R.S.O., K. Naser and A. Mora, 1994. The relation between the comprehensiveness of corporate annual reports and firm characteristics in Spain. Account. Bus. Res., 97: 41-53. http://direct.bl.uk/bld/PlaceOrder.do?UIN=023885 876\&ETOC $=\mathrm{EN} \&$ from $=$ searchengine 